\title{
茶浸出液中の残留農薬分析における酢酸鉛処理の効用
}

\author{
小野田恭久, 今村昌子 \\ 静岡県茶業試験場 \\ (昭和 54 年 7 月 21 日受理)
}

\section{Utility of Basic Lead Acetate Treatment for Analysis of Pesticides Residues in Tea Infusion}

\author{
Yasuhisa OnODA and Masako ImamuRA \\ Shizuoka Tea Experiment Station, Kikugawa, Shizuoka 439, Japan
}

\begin{abstract}
The procedures on the residual analysis of pesticides, DMTP (methidathion), isoxathion, methomyl, PAP (phenthoate), phosalone and TPN (chlorothalonil) were simplified by some modifications. Basic lead acetate solutions added to tea infusion to precipitate polyphenols and saponins as lead complexes. These lead complexes were filtered through a filter paper piled with some celite, and washed with $50 \mathrm{ml}$ of acetone and then $100 \mathrm{ml}$ of $n$-hexane. In case of methomyl, the remnant was washed with $50 \mathrm{ml}$ of ethanol.

From the resulting aqueous layer, chemicals except methomyl were extracted with $n-$ hexane and cleaned up by column chromatography. In Florisil column chromatography, the first eluate with ether containing $50 \%$ of $n$-hexane contained isoxathion, and the next eluate with ether containing $50 \%$ of benzene contained DMTP and phosalone. PAP and TPN were eluted with $n$-hexane containing $20 \%$ of ether in silica-gel column chromatography. Methomyl was extracted with ethyl acetate from solution alkalified with sodium hydroxide and superheated for over $30 \mathrm{~min}$.

The recovery ranged between 87 and 100\% in DMTP, isoxathion, PAP, phosalone and TPN, and $86 \%$ in methomyl.

Using $6 \mathrm{~g}$ of the tea sample, the lower limits of detection of each chemical were 0.003 ppm (TPN), $0.03 \mathrm{ppm}$ (methomyl, PAP), $0.04 \mathrm{ppm}$ (DMTP) and $0.05 \mathrm{ppm}$ (isoxathion, phosalone) in the obtained tea infusion each $360 \mathrm{ml}$ of which had been subjected to the analysis.
\end{abstract}

緒言

現在, 食品中の各種農薬の残留分析は多くの場合環境 庁が告示した方法（以下告示法という）により行なわれ ている．しかし，対象となる食品，作物が含有する特殊 成分あるいは，その量の多少によりそれらの分析に告示 法の直接適用が困難な場合が少なくない.

茶葉はタンニンに代表されるポリフェノール類を多量 に含み，それらが分析障害となる可能性が非常に大き い. 茶浸出液から譨薬を抽出するさい, 茶浸出液と抽出
溶媒の間にエマルジョンが生成し，これが長時間静置し ても消滅しない等の問題が起きている.

そこで，茶の糖類定量法に採用されている1 ${ }^{1}$ 塩基性酢 酸鉛液を用いる除タンニン操作を, 茶浸出液に添加し た DMTP, イソキサチオン, メソミル, PAP, ホサロ ン, TPN の分離操作に適用した. この結果, 溶媒によ る分離抽出が良好となり, 回収率が向上したばかりでな く,メソミル以外の農薬は同時抽出精製が可能となるな ぞ，茶の農薬分析法が簡易，迅速化されたので報告す る. 


\section{実 験 方 法}

\section{1. 試薬および装置}

1）塩基性酢酸鉛液

試薬特級の中性酢酸鉛と酸化鉛を $43: 13$ の割合にと り, 水で 30 分間煮沸溶解し, 飽和溶液とし, 残留農薬 試験用 $n$-ヘキサンで洗浄したもの.

2) フロリジル

フロリジル社製，60〜80 メッシュ

3) シリカゲル

ワコーゲル C-200

4) 農薬標準品

DMTP, イソキサチオン, メチルチオアセトヒドロキ シマート, PAP，ホサロン, TPN とも純度 $98 \%$ 以上, 和光純薬 (株) 製, メソミルはクミアイ化学(株) より提 供.

5）その他の試薬

残留農薬試験用試薬または試薬特級.

6) ガスクロマトグラフ

柳本製作所製 $\mathrm{G}-80$ 型 [FPD]，同 G-1800 型 [ECD $\left.\left({ }^{63} \mathrm{Ni}\right)\right]$.

\section{2. 分析操 作}

1) 農薬添加試料の調製

茶浸出液への農薬標準品の添加は, メソミルの場合は 水溶液, DMTP, イソキサチオン, PAP, ホサロン, TPN についてはアセトン溶液を作成して添加した。

2）環境庁告示法

官報に記載されている方法によった 2 (6).

3）改良分析法

i) メソミル定量法7)

茶 $9 \mathrm{~g}$ に熱湯 $540 \mathrm{ml}$ を加え 5 分間放置する. 得られ た茶浸出液の $360 \mathrm{ml}$ に塩基性酢酸鉛液 $5 \mathrm{ml}$ を加え, ふり混ぜたのち 5 分間静置し，ポリフェノール類を沈殿 させる．漏斗上にセライト 545 を $10 \mathrm{~g}$ 程度敷いた濾紙 を用いて吸引濾過し，漏斗上の残椬をエタノール $50 \mathrm{ml}$ を用いて洗い，濾液に合する，全濾液中の過剩の鉛を $10 \mathrm{~N}$ 硫酸 $5 \mathrm{ml}$ の添加により沈殿させ, 濾過除去する. この濾液を $10 \mathrm{~N}$ 水酸化ナトリウム溶液添加によりアル カリ性とし，湯浴中 $90^{\circ} \mathrm{C}$ で 30 分以上の加熱を行なう. 冷却後, この溶液を $1 l$ 分液漏斗に移し，酶酸エチル $250 \mathrm{ml}$ を加え，5分間振とうし，酢酸エチル層を分取す る.さらに水層に䣷酸エチル $250 \mathrm{ml}$ を加え，5分間振 とうし，酢酸エチル層を分取する．全酢酸エチル層に無 水硫酸ナトリウムを加え， 30 分間脱水した後， $40^{\circ} \mathrm{C}$ 以 下でトリエチルアミン $1 \mathrm{ml}$ を添加して減圧濃縮を行な
い, 約 $1 \mathrm{ml}$ とする. これを窒素ガスを用い乾固し, 酢 酸エチルの一定量 $(2 \sim 4 \mathrm{ml})$ に溶解し, 試験液とし, FPD (Sf)-GC により定量する.

ii) DMTP, イソキサチオン, PAP, ホサロン, TPN 定量法

(1) 茶浸出液からの分離抽出

茶浸出液について, メソミルの場合と同様に塩基性酢 酸鉛による処理を行ない吸引濾過する，このとき，漏斗 上の残渣は，まず水 $20 \mathrm{ml}$ で洗い，ついでアセトン 50 $\mathrm{ml} n$-ヘキサン $100 \mathrm{ml}$ の順で洗い濾液に合する. 全濾 液を $1 l$ 分液漏斗に移し， 5 分間振とうしへキサン層を 分取する．さらに水層に $n$-ヘキサン $100 \mathrm{ml}$ を加え，同 様の操作後一キサン層を分取し，全一キサン層を無水硫 酸ナトリウムで脱水する.これを $40^{\circ} \mathrm{C}$ 以下で $1 \mathrm{ml}$ 程 度まで減压濃縮し, 窒素ガスによる乾固の後, $n$-ヘキ步 ソ $5 \mathrm{ml}$ を加え溶解し，抽出液とする。

(2) カラムクロマトグラフィーによる精製

A）フロリジルカラムクロマトグラフィー

フロリジル $5 \mathrm{~g}$ をnーヘキサンを用いてクロマト管(内 径 $1.5 \mathrm{~cm}$ ，長さ $30 \mathrm{~cm}$ ) に充てんする.このとき，フ ロリジルの下部に $1 \mathrm{~cm}$, 上部に $2 \mathrm{~cm}$ 程度無水硫酸ナ トリウムを充てんする，これに前述の抽出液を $n$-へキ サンを用いて流し込む。第 1 溶出液として 50\% エチル エーテル・n-ヘキサン $100 \mathrm{ml}$ を，第 2 溶出液として $50 \%$ エチルエーテル・ベンゼン $100 \mathrm{ml}$ を用いて溶出 し，それぞれの溶出液を $40^{\circ} \mathrm{C}$ 以下で $1 \mathrm{ml}$ 程度まで減 压濃縮し，窒素ガスを用いて乾固した後，n-ヘキサンの 一定量 $(2 \sim 4 \mathrm{ml})$ で溶解し, 試験液とする.

このとき，第 1 溶出による試験液中に PAP， イソキ サチオン，ホサロンが得られ，第 2 溶出による試験液中 には DMTP のみが得られる。

B） シリカゲルカラムクロマトグラフィー シリカゲル $5 \mathrm{~g}$ をフロリジルの場合と同様の操作でク ロマト管に充てんする。これに前述の操作で得た抽出液 をnーヘキサンを用いて流し込む。溶出液として $20 \%$ エ チルエーテル・n-ヘキサン $100 \mathrm{ml}$ を用いる. 得られた 溶出液を $40^{\circ} \mathrm{C}$ 以下で $1 \mathrm{ml}$ 程度まで減圧濃縮し, 窒素 ガスにより乾固した後, $n$-ヘキサンの一定量 $(2 \sim 4 \mathrm{ml})$ で溶解し試験液とする．この試験液中に PAP と TPN が得られる。

なお，カラムクロマトグラフィーによる各農薬の分離 精製法を Table 1 にまとめた.

4) ガスクロマトグラフィーの操作条件

各農業に対するガスクロマトグラフィーの操作条件は Table 2 にまとめた。 
Table 1 Clean up procedures of some pesticides by column chromatography.

\begin{tabular}{|c|c|c|c|}
\hline \multicolumn{2}{|l|}{ Eluting method } & \multicolumn{2}{|c|}{ Support } \\
\hline Solution & Volume (ml) & Florisil (5 g) & Silica-gel (5 g) \\
\hline $20 \%$ ether-hexane & 100 & PAP & PAP TPN \\
\hline $50 \%$ ether-hexane & 100 & PAP Isoxathion & $\overline{\text { Isoxathion PAP }}$ \\
\hline $50 \%$ ether-benzene & 100 & $\begin{array}{l}\text { DMTP Isoxathion } \\
\text { Phosalone }\end{array}$ & $\begin{array}{l}\text { Phosalone TPN } \\
\text { DMTP Phosalone }\end{array}$ \\
\hline $50 \%$ ether-hexane (1st) & 100 & & \\
\hline$\{50 \%$ ether-benzene $(2 \mathrm{nd})$ & 100 & DMTP & DMTP \\
\hline
\end{tabular}

Elution efficiency of each pesticide was almost $100 \%$.

The underlines showed the most suitable conditions for each pesticide.

Table 2 Operating conditions of gas-chromatography for some pesticides.

\begin{tabular}{|c|c|c|c|c|c|c|}
\hline Condition & DMTP & Isoxathion & Methomyl & PAP & Phosalone & TPN \\
\hline Column (glass) & $75 \mathrm{~cm}-3 \mathrm{~mm}$ & $75 \mathrm{~cm}-3 \mathrm{~mm}$ & $75 \mathrm{~cm}-3 \mathrm{~mm}$ & $75 \mathrm{~cm}-3 \mathrm{~mm}$ & $75 \mathrm{~cm}-3 \mathrm{~mm}$ & $100 \mathrm{~cm}-3 \mathrm{~mm}$ \\
\hline Packing & $10 \% \mathrm{XE}-60$ & $1.5 \% \mathrm{OV}-17$ & $10 \%$ FFAP & $15 \% \mathrm{SE}-30$ & $1.5 \% \mathrm{OV}-17$ & $5 \% \mathrm{DC}-200$ \\
\hline $\begin{array}{l}\text { Support } \\
\quad(60-80 \mathrm{mesh})\end{array}$ & $\mathrm{GC}-\mathrm{Q}$ & $\mathrm{GC}-\mathrm{Q}$ & $\mathrm{GC}-\mathrm{Q}$ & $\begin{array}{l}\text { Chromosorb } \\
-\mathrm{W}(\mathrm{AW})\end{array}$ & $\mathrm{GC}-\mathrm{Q}$ & $\begin{array}{l}\text { Chromosorb- } \\
\text { W (AW) }\end{array}$ \\
\hline $\begin{array}{l}\text { Carrier gas } \\
\qquad\left(\mathrm{N}_{2} \mathrm{ml} / \mathrm{min}\right)\end{array}$ & 50 & 65 & 35 & 50 & 65 & 40 \\
\hline Column temp. & $230^{\circ} \mathrm{C}$ & $228^{\circ} \mathrm{C}$ & $170^{\circ} \mathrm{C}$ & $220^{\circ} \mathrm{C}$ & $250^{\circ} \mathrm{C}$ & $175^{\circ} \mathrm{C}$ \\
\hline Injection temp. & $275^{\circ} \mathrm{C}$ & $250^{\circ} \mathrm{C}$ & $190^{\circ} \mathrm{C}$ & $250^{\circ} \mathrm{C}$ & $300^{\circ} \mathrm{C}$ & $270^{\circ} \mathrm{C}$ \\
\hline Detector temp. & $300^{\circ} \mathrm{C}$ & $300^{\circ} \mathrm{C}$ & $250^{\circ} \mathrm{C}$ & $300^{\circ} \mathrm{C}$ & $350^{\circ} \mathrm{C}$ & $270^{\circ} \mathrm{C}$ \\
\hline Detector & FPD-Pf & FPD-Pf & FPD-Sf & FPD-Pf & FPD-Pf & $\mathrm{ECD}$ \\
\hline Retention time (min) & 2.0 & 2.0 & 2.0 & 3.0 & 2.0 & 4.0 \\
\hline
\end{tabular}

Flow rates of hydrogen and air were adjusted to the most suitable conditions of each detector response.

5) 検量線の作成

メソミル（分析対象物はメチルチオアセトヒドロキシ マート）は，標準品を酢酸エチルに，他の農薬は $n$-へ キサンに溶解し， $0.01 \sim 2$ ppm の標準溶液を作成する. ただし，TPN については，0.0005〜 1 ppm 溶液とす る.この標準溶液の $4 \mu 1$ を前記条件のガスクロマトグ ラフに注入し測定する. いずれもピーク高による絶対検 量線法を用いた. メソミルの場合, ピーク高の平方根を とると検量線は直線となった。

\section{実験結果および考察}

\section{1. メソミル}

Table 4 から明らかなように, 改良法のメソミルの回 収率は告示法に比較し, 格段と勝れていた。

これは, 告示法に拈いて, クロロホルム $50 \mathrm{ml}, 2$ 回 の抽出では, 水溶性であるメソミルのクロロホルム層へ の転溶が不十分であることと, クロロホルムと茶浸出液 を混合振とうするさいにエマルジョンが生成し, 両層の
分離が不完全になること等が，回収率を低下させている 原因と考えられる.このエマルジョンの生成は, 主とし て茶浸出液中に含まれているポリフェノール類によるも のと考えられた。

\section{DMTP, イソキサチオン, PAP, ホサロン, TPN}

Table 4 の結果で明らかなように, 告示法による回収 試験でも TPN をはじめ, 各農薬とも高い回収率が得ら れ, 同法が不適とは考えられなかった. しかし, 茶浸出 液と抽出溶媒の混合振とう時に多量のエマルジョンが生 成し, 分離が不十分となり, 分取のさいに多量の水分が 混入し, その脱水に多量の無水硫酸ナトリウムを必要と し, 処理操作に長時間を要すること.イソキサチオンの 場合は, 抽出溶媒の $n$-ヘキサン量が $50 \mathrm{ml}$ と少量のた め, 生成するエマルジョンにより分離が非常に悪く, 分 取も $2 / 3$ 以上が水分となり，このような状態では溶媒抽 出の効果があげられないこと. DMTP とホサロンの場 合は, 測定のさいガスクロマトグラム上で妨害ピークと 重なりを生じ, 測定誤差を招くおそれがあるなど, 告示 
Table 3 Lower limits of detection of some pesticides in tea infusion.

\begin{tabular}{lcc}
\hline Pesticide & $\begin{array}{c}\text { Sample } \\
\text { volume } \\
(\mathrm{ml})\end{array}$ & $\begin{array}{c}\text { Lower limit } \\
\text { of detection } \\
\text { (ppm) }\end{array}$ \\
\hline Methomyl & 360 & 0.03 \\
DMTP & 360 & 0.04 \\
Isoxathion & 360 & 0.05 \\
PAP & 360 & 0.03 \\
Phosalone & 360 & 0.05 \\
TPN & 360 & 0.003 \\
\hline
\end{tabular}

法には多くの問題点が認められた。

これに対し，改良法ではェマルジョンの生成は認めら れず，茶浸出液と抽出溶媒の分離が完全となり，脱水も 少量の無水硫酸ナトリウムで容易に行なわれ，妨害ピー クも除去でき，回収率も向上するなど，告示法にみられ る問題点はほとんぞ解決された。

しかし，TPN 分析の場合，酶酸鉛処理により生じた 沈殿物の滤過操作で, 残渣中に TPN の大部分が残存し て打り，これは $n$-へキサン $100 \mathrm{ml}$ の洗浄では溶出が 不十分であったが，アセトン $50 \mathrm{ml}$ による洗浄操作を加 えたところ，完全に溶出することができた。

こうして同時抽出された 5 種類の農薬の分離を，カラ ムクロマトグラフィーで行なったが，フロリジルおよび
シリカゲルを用いたカラムクロマトグラフィーでは， Table 1 に示したように, その溶出液の組成を変えるこ とにより，各農薬の精製が良好に行なわれた。

フロリジルを用いた場合，TPN の溶出にはアセトン が必要であるが，このとき，吸着された色素も同時に溶 出され，ガスクロマトグラム上で妨害ピークが現われる ため不適当であったが，イソキサチオン，木サロン等の 農薬については Table 1 の溶出液による精製で無色透 明の試験液を得ることができた。

また，DMTP の精製の場合，50\% エーテル・ベンゼ ンで 100\% の溶出は可能であるが，ガスクロマトグラ ム上に妨害ピークが現われる。これらの妨害成分は， DMTP 吸着カラムを $50 \%$ エーテル・へキサンで洗浄 することにより完全に溶出除去できるので，この操作後 に DMTP を溶出するのがよいと判断した.

PAP と TPN の分離精製には，シリカゲルを用いた $20 \%$ エーテル・ヘキサン溶出のほうが，ガスクロマト グラム上の妨害ピークも少なく適していたが，他の農薬 については，試験液が透明ではあるが薄黄色となるた め，必要なとき以外は避けたほうが無難であると思われ る.

塩基性酶酸鉛による除タンニン操作は，アセトン等に よる直接抽出液に打いても好結果を得ており（メソミ ル，ホサロン)，広範囲に活用できるものと思われる。

Table 4 Recoveries of some pesticides from tea infusion.

\begin{tabular}{|c|c|c|c|c|}
\hline Pesticide & Method & $\begin{array}{c}\text { Added } \\
\text { amount }(\mu \mathrm{g})\end{array}$ & $\begin{array}{l}\text { Recovery } \\
(\%)\end{array}$ & Remark \\
\hline \multirow[t]{2}{*}{ Methomyl } & E.A. & $\begin{array}{l}2.2 \\
4.4\end{array}$ & $\begin{array}{l}<10 \\
<10\end{array}$ & Concentrated solution contained precipitation \\
\hline & Proposed & 4.4 & 86.7 & Concentrated solution was clear pale green \\
\hline DMTP & $\begin{array}{l}\text { E.A. } \\
\text { Proposed }\end{array}$ & $\begin{array}{l}2.08 \\
1.94\end{array}$ & 97.0 & Emulsification was heavy \\
\hline \multirow[t]{2}{*}{ Isoxathion } & E.A. & 2.2 & difficult & $\begin{array}{l}\text { Separation was difficult because of emulsifica- } \\
\text { tion }\end{array}$ \\
\hline & Proposed & 2.2 & 100 & \\
\hline \multirow[t]{2}{*}{ PAP } & E.A. & $\begin{array}{l}3.14 \\
6.28\end{array}$ & $\begin{array}{l}74.0 \\
78.8\end{array}$ & Emulsification was heavy \\
\hline & Proposed & $\begin{array}{l}2.0 \\
3.14\end{array}$ & $\begin{array}{l}90.0 \\
98.0\end{array}$ & \\
\hline \multirow[t]{2}{*}{ Phosalone } & E.A. & 2.4 & 82.3 & $\begin{array}{l}\text { Measurement was difficult because of inter- } \\
\text { fering peaks }\end{array}$ \\
\hline & Proposed & 2.4 & 96.6 & \\
\hline \multirow[t]{2}{*}{ TPN } & E.A. & 0.168 & 70.5 & Emulsification was heavy \\
\hline & Proposed & $\begin{array}{l}0.168 \\
3.34\end{array}$ & $\begin{array}{l}87.8 \\
92.0\end{array}$ & \\
\hline
\end{tabular}

Tea infusion volume was $360 \mathrm{ml}$.

E.A.: the method notified by Environmental Agency. 


\section{要約}

茶浸出液中の残留農薬分析操作に，塩基性酶酸鉛によ る除タンニン操作を加光, 各農薬の抽出法を検討し, 以 下のような結果を得た。

1）茶浸出液と抽出溶媒間のエマルジョンの生成が抑 制され，分離が良好となり，脱水操作も短時間に行なう ことができ，告示法にくらべ高回収率を得ることができ た.

また，このとき大部分の色素類も同時に除去され，ガ スクロマトグラム上の夾雑ピークの数も減少するなど, 茶浸出液中の残留農薬分析に打いて, 塩基性酶酸鉛によ る除タンニン操作はきわめて有効な手段であった。

2）メソミルの抽出溶媒は酶酸エチルがよく, 告示法 の操作を省略できた。

3）告示法では，DMTP，イソキサチオン, PAP，木 サロン，TPN で抽出精製法がすべて異なっているが， 本試験の結果，同一溶媒による同時抽出が可能となり， 操作の省略や抽出溶媒の種類を少なくすることができる など，分析試料の調整法が簡便となった。
本試験を行なうに当たり，有益なご助言を賜わった農 林水産省農産園芸局植物防疫課 石井康雄氏（元 農林 水産省農薬検査所), 農林水産省茶業試験場 竹尾忠一 博士に厚く打礼申しあげる.

また，メソミル純品を提供していただいたクミアイ化 学工業株式会社に深く感謝する.

\section{引用 文 献}

1）岩浅 潔・中島末秋・中川致之：茶技研 44，4447 (1972)

2）官報 第 14503 号，DMTP，メソミル試験法 (1975 年 5 月 10 日）

3）官報 第14978 号, イソキサチオン試験法 (1976 年 12 月 10 日)

4) 官報第 14310 号, PAP 試験法 (1974 年 9 月 9 日)

5）官報 第 14746 号，ホサロン試験法（1976 年 3 月 4 日）

6) 官報 号外第 15 号, TPN 試験法（1974 年 3 月 19 日)

7）小野田恭久 · 今村昌子：茶研報 48，40-45（1978） 